\title{
$\mathrm{S} / \mathrm{E} \geq 1:$ \\ A semiotic understanding of bioengineering
}

\author{
Jesper Hoffmeyer \\ Department of Biological Chemistry, University of Copenhagen \\ Solvgade 83, DK 1307 Copenhagen K, Denmark \\ e-mail: hoffmeyer@mermaid.molbio.ku.dk
}

\begin{abstract}
Natural (non-cultivated) systems are tuned to economize their use of energy as much as possible, and thereby to produce minimal amounts of entropy. It is suggested that this has been obtained by optimizing the evolutionary creation of semiotic controls on all processes of life. As long as biological (ultimately photosynthetic) energy sources satisfied most human needs for energy consumption, these biosemiotic controls remained largely undisturbed, with the result that production systems remained sustainable. The industrial revolution instantiated a rupture of this balanced situation. The semiotic control function $(S)$ would no longer match the size of the energy flow $(E)$. In the industrial production system, energy flows have dramatically been increased, while the $S$ component has not been taken care of. This has created a dangerously low $S / E$ ratio, and it is suggested that this low $S / E$ ratio constitutes a fundamental explanation of the environmental crisis. In order to restore a sustainable production system, we will now have to develop technological means for a strong increase in the $\mathrm{S}$ factor of the production system. It is suggested that this can be obtained through a development of considerate, gentle, and clever forms of biosemiotic technology.
\end{abstract}

The basic idea behind this paper came to me already while I worked on my book of 1982 on ecological history, Samfundets naturhistorie (Natural History of Society; not translated into English; Hoffmeyer 1982). In the meantime, I always hoped to work it out in more satisfactory details and depth. But in order to do this, one must ideally combine a thorough understanding of history with a sure command of several very different kinds of competencies, primarily biochemistry, ecology, technology, and semiotics. Since obviously I cannot claim 
such diversified skills, I am now offering the basic idea here in the hope that somebody else might find the time and power to substantiate it. It seems to me that if the idea may in fact be substantiated, it should have a decisive influence on our thinking in areas of ecology and technology. So, even though the idea is yet just a sketch, I think a presentation must be risked.

\section{Energy and semiosis}

It may be seen as a case of cultural bias that the term energy is now part of everyday language while its counterpart term in thermodynamics, entropy, is not even known to the man in the street. Abundant supplies of energy are the well-known motivating force behind the show we call the modern world, whereas production of entropy is related rather to certain negative aspects of this show such as thermal and chemical pollution or ecological disorder. That there is a necessary link between these two major players of our world is not generally acknowledged, even though physics has it as one of its most fundamental laws, the 2 nd law of thermodynamics. According to the second law of thermodynamics, the amount of entropy in a system is bound to increase whenever an energy transformation takes place. And this fact may well be one of the deepest pieces of knowledge we have about our universe.

One way of describing the meaning of entropy is as "molecular disorder" and this shows us how the concept relates to pollution. For illustration, one important component of fertilizer is phosphate, which is mined from a variety of deposits. When fertilizer is spread over the open land, phosphate molecules formerly packed in the deposits become spread out not only in the fields, but also wherever rain and streams will take them. Thus, much of the phosphate ends up stimulating the growth of algae, followed by oxygen depletion in rivers, lakes, and coastal waters. In this situation, the phosphate molecules have literally become disordered, since we now know less about their localization than we did before.

The 2nd law of thermodynamics has often been seen as a law of general degradation and thus as contradictory to the existence of life and evolution. However, the apparent contradiction was solved in 1945 by the physicist Erwin Schrödinger who in his seminal book What is life? explained how the evolution of life on Earth has pro- 
ceeded without any violation of the 2 nd law (Schrödinger 1945). For this to happen, the only condition is that the surplus production of entropy linked to the metabolic processes of life would somehow be exported away from the system, which is in fact exactly what happens when disorganized heat energy is irradiated away from the planet. Thus, in the overall scheme, highly organized and thus low-entropic irradiation reaches planet Earth from the sun whereas high-entropic heat energy is given off to outer space. The flow of energy through the planetary system thus carries a net export of entropy away from the earth allowing for the build up of organized low-entropy structures and behaviours associated to the processes of life.

In the 1970s, Ilya Prigogine and his co-workers found that the 2nd law, when applied to systems far from equilibrium would actually account for the occasional creation of organized states out of chaotic states (Prigogine 1980). Following this work, for which Prigogine was accorded the Nobel price, a number of more radical interpretations of the 2nd law have been suggested (see, e.g., Ulanowicz 1997 for an overview). Essentially, the organizing and degradative powers of our physical world belong together and are ultimately derived in the condition of irreversibility described by the 2 nd law.

Semiosis then, as the manifestation of Nature's tendency to take habits, is rooted in the irreversible entropic dimension of our universe. Ultimately, semiosis derives from the weak kind of "future directedness" implied by irreversibility, or in other words from the possibility of "knowledge" or "memory", in the broadest sense of these concepts, which is latently implied by any form of directionality. About a reversible world you cannot know a thing, but an irreversible world necessarily opens itself to eventual anticipation.

Historians may discuss whether or not human history has progressed in the sense of our civilizations, attaining a higher quality of life or of other eventual parameters connected to human well being. However, it is an undeniable fact that the flow of energy which human societies have been able to canalize into productive social use has exhibited a nearly unbroken pattern of increase throughout history (Hoffmeyer 1982; 1988). Major steps were the appropriation of biological or photosynthetic energy flows through the agricultural revolution, the taming of the non-biological but natural energy flow of hydrological power during the middle ages (the water wheel) and of 
course the mastering of artificial energy flows derived from coal, oil, or uranium ${ }^{1}$.

All of this depended upon the development of highly sophisticated semiotic controls frozen into technology and into social organization and co-operation patterns (Hoffmeyer 1988). Energy per se is of no use; for energy to be useful it must be brought to "flow" according to human needs.

But what is true of human productive life is no less true of the millions of other species trying to cope with the thermodynamic bindings of energy metabolism. In nature as in culture, entropy production has to be kept at a minimum or exported to the surroundings, and in both cases this is obtained by semiotic means. Energy and semiosis are the two major players in the evolutionary game on Earth.

\section{An ecohistorical perspective}

According to C-14 dating, wheat production started 9,500 years ago in southeastern Europe and slowly spread along an axis from south east to northwest reaching the farthest northwestern regions appr. 5,000 years ago (Cavalli-Sforza 2000). Compared to the short span of time, a few hundred years, during which we have had industrialized societies, peasant societies had been exceedingly stable. In fact, traditional peasant economies were potentially sustainable economies, although environmental catastrophes were indeed threatening whenever land became too heavily populated.

But even 10,000 years is a short span of time as compared to the period of 100,000 or 150,000 years during which our own species has inhabited the earth, living, we must presume, in band societies based on hunting and collecting. Thus, seen from the point of view of hunter-collector societies, even agricultural production may seem to touch on the edge of sustainability.

In Hoffmeyer (1982), I dealt extensively with the ecology of early human technological history (see also Hoffmeyer 1988). Let me here summarize a few points.

Hunting and collecting is a very extensive way of life because very few resources can be extracted from nature when the most important

${ }^{1}$ Coal and oil are of course perfectly natural sources of energy. What is artificial is the flow, i.e., the burning up of those enormous deposits in the time span of a few centuries. 
energy source is unmanipulated nature and when the energy-technique does not in general exceed the limits of muscular power - bound as that power necessarily is to the restraints of the human body. No gradual process can increase the amount of resources accessible by this strategy beyond a naturally given level.

This naturally determined threshold (reflecting the available means of food-energy per $\mathrm{km}^{2}$ of wild nature) probably constitutes the most important natural fact in human history. The significance of this threshold was that the only way to sustain life for a population density above a certain level was to embark on the laborious practices of cultivating the earth, i.e., agriculture.

The essence of agriculture is that it surpasses the threshold set by unmanipulated natural systems and brings to productive use a radically simplified biological system, the field. Through agriculture, men and women get access to biological energy resources (photosynthesis) in a systematic way and thereby they can suddenly increase the absolute amount of resources extracted per areal unit enormously, allowing for the survival of much denser populations.

It should be noticed, however, that contrary to legend, people in general do not want to cultivate the soil if they don't have to. The point is, that the control of photosynthesis, i.e., systematic biological energy, is a survival strategy which changes any dimension of people's social life. This is born out by anthropological and archeological evidence as well as by theoretical considerations (Lee 1968; cf. Boserup 1965; Wilkinson 1973; Harris 1977). Hunter collectors resist the introduction of agriculture, primarily because the necessary workload is radically increased and also because social freedom and autonomy is decreased. The continued intensification of agriculture apparently leads inevitably to a doubling — or even a tripling (in irrigationsystems) - of the amount of social work. The anthropologist Marshall Sahlins even coined the term "the original affluent societies" for the hunter-collector cultures of the Stone Age (Sahlins 1972). Thus, the agricultural revolution has probably nowhere in the world been a voluntary process (Carneiro 1970).

Behind these facts lies an important ecologically based principle, namely that the flow of resources extractable from a given area can only be increased through operations which push natural systems farther away from their own balanced state (Hoffmeyer 1988). However, to do this, not only more energy (which in pre-industrial societies means work) but also a stricter organization is needed. Inevitably then, the flow of resources becomes more and more dependent on condi- 
tions which are liable to social manipulation. Therefore, a connection exist between the size of a given flow of resources and the social manipulability of this same flow.

Thus, in the case of the agricultural revolution, people from now on had to organize their work in particular ways, reflecting the characteristics obtaining to the management of a harvest-surplus. Work becomes heavier and is no longer individual. Planning and co-operation become necessary for raising, storing, and distributing the harvest surplus. From those requirements, finally, the possibility for one class to monopolize the flow of resources is derived. Agriculture simply establishes for the first time in history conditions akin to the project of controlling somebody else's access to his resources, i.e., the ownership of land. And, as the British historian Richard Wilkinson has put it: "Power stems inevitably from control of people's access to their means of livelihood" (Wilkinson 1973: 110).

The capacity for resource appropriation by photosynthetic energy sources had probably been locally exhausted as early as in the old high-cultures of Egypt, Mesopotamia, or China. However, the possibility for expansion all over the globe probably worked like a valve letting out the pressure, and thousands of years had to pass before the next natural threshold was crossed.

This happened in Europe in the late Middle Ages as a totally new technical principle was introduced in a systematic way: The principle of non-biological energy in the form of windmills and watermills. The peasants did not profit from these mills. Quite to the contrary, they were now forced by the landlord to grind their grain on the mill for payment.

The characteristic difference between biological and nonbiological energy sources is this: while living nature - and thus earth as material substrate - is essential to the former, inanimate nature (the hydrological cycle, coal, oil etc.) is the core of the latter. Living nature immediately furnishes people with nearly all of their material requirements, food and fodder, clothes, tree for building, natural fibres, construction and warming. A water mill (or coal) does none of this. Thus, while a society dependent on biological energy is most easily organized in a locally self-sufficient way and a power-relation based on ownership of land, a society based on non-biological energy is not only indifferent to but even incompatible with this kind of economic and political organization. The social logic of non-biological energy points towards a society based on division of labour and production for a market. 
The strong focus on the steam engine as the basic technological improvement behind the industrial revolution may have blinded us to the fundamental importance of these ecologically based aspects of the major transformations in history. From an ecosemiotic point of view the transformation of a production system fuelled by biological energy to a production system based on nonbiological or artificial energy sources is of prime importance.

\section{The biosemiotics of the industrial revolution}

Through billions of years of evolution, plants and animals have acquired exceedingly sophisticated endo- and exosemiotic means of controlling the flows of energy on which they depend. The endosemiotic controls are exhibited through millions of ingeniously tuned biochemical and physiological cycles and, in the case of animals, through the senso-motorically controlled settings of behavioural patterns. The exosemiotic controls exhibit a diverse and far from well-understood group of interspecific interaction patterns. Symbiotic relations (mutualism and parasitism) offer prominent examples of exosemiotic controls on energy flow (Sapp 1994; Hoffmeyer 1997c), but in general, any biotic or nonbiotic regularity in nature may serve as orientation marks for some species or other, thus diverting energy flows through natural biota in subtle and semiotically well scaffolded patterns (Hoffmeyer forthcoming).

The point I want to make here is that evolution has worked relentlessly on fitting the biosemiotics of all species to the kinds of energy flows available to them and that therefore evolution guarantees a near optimal fit of the means for semiotic control to the actual flows of energy through bodies or ecosystems. Now suppose it was possible to measure this semiotic fitness, $S$, e.g., in terms of entropic efficiency. Then, for reasons just discussed, we would expect that $S$ in natural systems would balance the energy flows, so that for convenience, we could equal the ratio $S / E$ to 1 in natural systems (where $E$ measures the size of the energy flow through the system). ${ }^{2}$

\footnotetext{
${ }^{2}$ I have no intention whatsoever to claim that a true quantifiable measure of semiotic fitness $(S)$ can in fact be constructed. But as a thought experiment, I think the idea of such a measure bears out the main point I am aiming at here, which is that a deeply disturbed relation between semiotic and energetic command is the key to the nonsustainability of industrial production systems.
} 
Now, as I said, the trick behind agriculture, is to produce a simplified ecosystem, the field, through which nearly all of the energy flow is canalized into one single species, i.e., the crop species. In preindustrialized societies, this takes an enormous amount of human labour, which in industrialized agriculture is substituted by a diversity of petrochemical products, such as fertilizer, herbicides, pesticides, and gasoline for motive power etc. Also, of course, the indirect energy costs of draining and digging ditches and canals, and of distributing the agricultural input as well as output (comprising construction of roads, railroads and bridges and of transportation vehicles, including tankers transporting oil and materials around the globe etc.) should be counted here.

Clearly, already in preindustrial agriculture, the amount of exosemiotic control on energy flows is lowered as compared to the state of wild ecosystems. On the other hand, this lowering of the $S / E$ ratio is at least partially compensated by human skill and ingenuity, and ultimately through the semiotic control exercised by the input of human knowledge. Thus, in healthy traditional agriculture, the yield is still low and essentially constrained by biosemiotically controlled natural nutrient cycles as well as by a whole range of non-biotic limit factors.

The industrial revolution meant that we learned how to bypass all or most of these natural constraints through an explosive increase in the use of artificial energy. In an agricultural production system based on the petrochemical service industry, an enormous homogenization of nature can be obtained, yielding unequalled amounts of crop. Or to state this in different words, industrializing agriculture meant that we learned to circumvent nature's own semiotic controls on energy flows, substituting them by few and comparatively very unsophisticated controls, such as time schedules for different kinds of operations like sowing, irrigating, spreading of fertilizer, herbicides and pesticides, and harvesting. I do not pretend here to offer a satisfactory comparison between the ecosemiotics of petrochemical agriculture and the ecosemiotics of more traditional kinds of agriculture, but I think that even in the absence of such a deep analysis, the overall picture is indisputable: the $S / E$ ratio is dramatically lowered. And this dramatic decrease, I shall suggest, is the deep source of the modern environmental crisis.

When we talk about an industrialized production system, we cannot limit ourselves to analyzing the agricultural sector, for agriculture is just one indissolvably integrated component of the diversified production apparatus of industrial society. From en ecological point of 
view, too, agriculture may well be the worst single factor in the deterioration of nature's capacity for sustainability, but by no means the only one. The overwhelming use of energy in all and every context of modern society (e.g., as chemicals ultimately derived from oil), inevitably end up overthrowing the semiotic controls operative inside living systems, at the organismic as well as at the ecological level (our own body included). Thus, in our estimate of the $E$ component we must include all kinds of energy flows staged by our production system.

In sum, we can see that the industrial revolution was only one half of a revolution. Starting with the water wheel in the Middle Ages and continuing through the mastery of coal, oil and uranium, we gradually liberated the energy component of natural systems from their biosemiotic controls. However, we did not until very recently try to evolve techniques to compensate for this liberation of the power of energy by a corresponding mastering of the power inherent in the biosemiotic controls. As a result, we created an ecological impoverishment of the environment reflecting the uninhibited dependence of our production system on the brute force of artificial energy. As a consequence, we are now unable to reestablish a sustainable production system, essentially because we have neglected the constraints ultimately induced upon us by the 2nd law of thermodynamics. The task ahead of us now is to embark on the second half of the so-called industrial revolution, which will consist in the development of a mastery of the biosemiotic controls which can match and thus sophisticate our mastery of the gigantic energy flows which in an overpopulated world necessarily must burden nature's ecological settings. Or, to state this more directly, we need to develop a biosemiotic technology base for our productive system, a technology base that can substitute natural biosemiotic controls by biosemiotic controls artificially set to obey human needs.

Therefore, instead of talking about the industrial revolution we should envisage that the deeper principle at work behind this major and yet sadly unfinished historical transformation has always been something quite different, namely, the substitution of a resource base relying on naturally controlled energy flows for a resource base relying on energy flows controlled by human ingenuity and skill. In fact, what we are witnessing is one long process of the humanization of nature. A process which slowly took off back in Neolithic times, then acquired an enormous momentum through the so-called industrial revolution and is now reaching a final turn where the dangerously dis- 
turbed tuning of the energetic and semiotic (entropic) aspects of the natural world has to be restored at a high artificial level.

\section{Clever technologies}

The American plant physiologist J. S. Boyer once calculated that the average harvest yield for a range of crops even in US agriculture was only $21.6 \%$ of a calculated maximum (Boyer 1982). Diseases, weeds and pests would account for less than $10 \%$ out of this total loss of nearly $80 \%$, whereas the rest would be due to unfitting physicochemical conditions such as lack of water, cold, high salt levels etc. As Boyer himself pointed out, the reason for this lack of efficiency is to be found in the current breeding strategies. Breeders typically produce a small number of "miracle" varieties, giving extremely high yields provided they are grown under favourable conditions. Now, the bad thing about the world is that conditions are rarely favourable, implying that farmers have to buy services from the petrochemical industries to artificially create a situation of "favourable conditions". However, as Boyer's numbers disclose, this strategy not only make farmers dependent on expensive and ecologically inflamed practices, it also apparently fails to deliver the true product, i.e., the favorable conditions.

The obvious solution to this problem is that instead of homogenizing the soils of the Earth so as to fit a few miracle crops, we should breed crops that fit the multitude of unfavourable conditions under which concrete farmers actually live. We need one particular kind of wheat for maximally favourable conditions, another for salty soils, yet another for soils that are too wet etc. Such a strategy, however, was not feasible within the paradigm of traditional cross-breeding where typically 10-15 years were needed for the production of each new variety. But new clever breeding technologies based on modern biotechnology, and particularly on genetic manipulation, have the potential to support a diversified breeding strategy aiming at producing varieties fitted to local conditions. ${ }^{3}$

${ }^{3}$ Whether political and economic conditions will permit the implementation of breeding for local needs is quite another question of course. Since multinational petrochemical industries are main actors on the breeding market, one should perhaps not be too confident that breeding for the purpose of uncoupling agriculture from petrochemical services will be a major priority. 
We are used to talking about clever technology as information technology, and it has often enough been claimed that we are now living in an information society. I think it is urgent that two points are made clear in this context. First, so-called information techniques (among which should be included techniques dealing with biological information) are not really techniques proper but meta-techniques, i.e., they are not directly interacting with the world around them. Instead, they are interacting with, and controlling other techniques. And, second, so-called information techniques may well be carrying out extraordinary amounts of information processing, but that is not their real power. The real power stems from their semiotic capacities, the semiotic control they assign to their user, the power of communicating and interpreting complex and quickly changing messages or patterns of cues. In fact, we ought to talk about semiotic techniques and not just information techniques.

A thought provoking illustration of this fact was given by Thomas Sebeok in his talk at the Toronto Conference, Semiosis, Energy, Evolution in 1997, when he nominated the Gulf War to be the first semiotic war in history. The key to American war-power in this case was not the pure data processing capacity of the American war machine. The key was rather the ability of ordinary soldiers to take command of all the smart technology, which again depended on the preceding development of user-friendly interfaces. The key to victory, in other words, was not information processing as such but rather semiotic command. And included in this semiotic command of course also were strategies for how to play in tune with the mass communication media, particularly television.

A gene technologically based breeding strategy to produce varieties for the world's variable local conditions is fundamentally a semiotic strategy. First, because it aims at persuading the plant species to grow well under specified conditions rather than to oblige them to do so by the application of brute force (petrochemistry), and second, because the strategy will only succeed if developed in an actual collaborative effort with local farmers.

The goal of breeding for local conditions is just one example out of a multitude of cases where the use of biosemiotic technology instead of petrochemical technology would accommodate our production system towards the goal of sustainability. To mention just one other example let me point to the striking fact that less than 30 plant species covers $95 \%$ of our total need for provisions, and just 3 grasses, wheat, rice and corn, alone furnish $75 \%$ of total human need for food. Why 
are so few of the world's estimated 300,000 species of plants in human use? The explanation seems to be historical coincidence, and this promises that unknown potentials are hiding in many other plant species, not only for production of crops for food and fodder, but also for production of crops intended as raw material for a fermentation industry, e.g., making bio-degradative plastic. Before world war two, chemical engineering was mainly based on biological raw materials, but this has all been forgotten in the petrochemical rush. Returning to biomass (semiotically tuned to our needs) as raw material will also fight the greenhouse effects because the $\mathrm{CO}_{2}$ intake of growing biomass balances off the $\mathrm{CO}_{2}$ contribution from using that same biomass.

Agriculture is, of course, by no means the only sector in which biosemiotic technology holds great promises for the goal of sustainability. Substituting chemical technology by biosemiotic technology wherever possible would be clearly favourable to the environment and probably less hazardous to health, too (although this need not be so and should be studied separately in each case).

My purpose here is not to offer an extensive analysis of the possibilities created by the development of biosemiotic technology. However, I hope that the discussion has substantiated my claim for the relevance of the general formula $S / E=K$ (where $K$ is supposed to average 1 in natural undisturbed ecosystems) as a guiding metaphor for our reflections on ecosemiotic strategies. The general effect of introducing biosemiotic technology will be to decrease the necessary deployment of energy due to a far better control of its effect on desired parameters, which of course amounts to saying that $\mathrm{S}$ is increased in the same time as E is decreased in the system. Thus, the introduction of biosemiotic technology will contribute to our goal of approaching the situation where $S / E \geq 1$, i.e., a sustainable production system.

\section{A natural history of society}

The very idea of the existence of ecologically based determinations of human history is probably anathema to most historians. One reason for this may be the general conception of the natural world as ruled by laws with deterministic power combined with the fact that deterministic conceptions of human history are not held in high esteem by modern historians. It should be remarked, therefore, that the idea presented here is not deterministic in any strong sense of the term. The claim is 
that cultural evolution has proceeded in accordance with constraints induced upon civilization by general thermodynamic and biological determinations. Nobody would object to gravity being a constraining factor for human life, and any psychological theory claiming that the attainment of unaided flight should be set as a goal for the upbringing of children, would rightly be ridiculed. Thus, our theories of society should likewise pay respect to fundamental thermodynamic constraints on human history. One cannot make perpetual mobiles and one cannot by hunting and collecting sustain population densities above appr. $2 \mathrm{~km}^{2}$ per person. Inside these constraining bonds, however, infinitely many concrete social ways of organizing life may be practiced as solutions to the constraining factors.

For perhaps one hundred thousand years our ancestors lived as hunter-collectors in small and, for all we know, egalitarian band societies. Then 10-11,000 years ago, quite suddenly agriculture was independently introduced in three different parts of the world. One possible explanation for this is the ecological breakdown in the aftermath of the final glacial period, caused, for instance, by gradual forestation of former grasslands which had been nourished by melt water from the now retreating glaciers. Together with the grasslands also the big wild game inhabiting these areas may have disappeared thus severely damaging survival conditions for the unfortunate hunters. Such conditions might have created the hard need that might have forced people into the laborious practices of cultivating the earth.

Whatever may have happened, there can be little doubt that this was a major catastrophe ${ }^{4}$, which catapulted our species out of its intimate or embryonic embeddedness in nature. Prehistory became history. The industrial revolution might seem to promise an end to the catastrophe of toilsome peasants' life. But this strategy of homogenizing nature by brute petrochemical force was doomed to create pollution and ecological disaster. The hope expressed in this paper is that a considerate, gentle and clever introduction of biosemiotic technology as a meta-technology to guide and control industrialized production will finally restore sustainability at a level which could nourish the high density of present populations on Earth.

${ }^{4}$ To give just one example: in fossil remains we can see that the neolithic revolution was accompanied by a dramatic decrease in average height, from $177 \mathrm{~cm}$

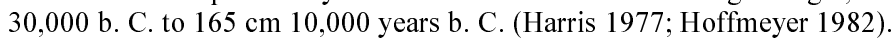




\section{References}

Boserup, E. 1965. The Condition of Agricultural Growth. New York: Allen \& Unwin.

Boyer, John S. 1982. Plant production and environment. Science 218: 443-448.

Carneiro, Robert L. 1970. A theory of the origin of the state. Science 169: 733738.

Cavalli-Sforza, Luigi L. 2000. Genes, Peoples, and Languages. New York: North Point Press and Farrar, Straus and Giroux.

Harris, Marvin 1977. Cannibals and Kings: The Origins of Cultures. New York: Random House.

Hoffmeyer, Jesper 1982. Samfundets naturhistorie. København: Rosinante.

- 1988. The historical logic of domestication. In: Thill, G.; Kemp, P. (eds.), The Triumph of Biotechnologies: The Domestication of the Human Animal (Acte du Cours de l'Inter-University Centre, Dubrovnik, March 1986). Namur: Presse Universitaires de Namur, 107-115.

- 1997c. Biosemiotics: Towards a new synthesis in biology. European Journal for Semiotic Studies 9(2): 355-376.

- (forthcoming). Semiogenic scaffolding in nature. Communication and Information Science Research 1.

Lee, Richard B. 1968. What hunters do for a living. In: Lee, Richard B.; Vore, Irven de (eds.), Man the Hunter. Chicago: Aldine.

Prigogine, Ilya 1980. From Being to Becoming. San Fransisco: Freeman.

Sahlins, Marshall 1972. Stone Age Economy. Chicago: Aldine.

Sapp, Jan 1994. Evolution by Association: A History of Symbiosis. New York: Oxford University Press.

Schrödinger, Erwin 1945. What is Life? London: Cambridge University Press.

Ulanowicz, Robert E. 1997. Ecology, the Ascendent Perspective. New York: Columbia University Press.

Wilkinson, Richard G. 1973. Poverty and Progress: An Ecological Model of Economic Development. London: Methuen.

\section{$\mathrm{S} / \mathrm{E} \geq 1$ : семиотическое понимание биотехнологии}

Природные (некультивированные) системы в максимально возможной степени ориентированы на экономизацию потребления энергии и поэтому птроизводят минимальное количество энтропии. В статье говорится о том, что такое положение достигнуто эволюционно, путем создания оптимальных семиотических контрольных механизмов для всех жизненных процессов. До тех пор, пока источники биологической (в конечном итоге фотосинтетической) энергии обеспечивали болышую часть энергетических нужд человека, эти биосемиотические системы 
контроля оставались преимущественно нетронутыми, в результате чего и производственные системы оставались стабильными. Индустриальная революция резко нарушила это равновесие. Функция семиотического контроля (S) не соответствовала уже величине энергетического потока (Е). В индустриальной производственной системе энергетические потоки заметно возросли, в то время как компонент $S$ остался в тени. Это привело к опасно низкой величине пропорции $S / E$, и в статье предполагается, что эта низкая величина и является основным объяснением экологического кризиса. Для восстановления устойчивой системы производства теперь необходимо развивать технические средства, чтоб заметно увеличить фактор $S$. Этого можно достичь, развивая гибкие, мягкие и разумные формы биосемиотической технологии.

\section{S/E $\geq 1$ : semiootiline arusaam biotehnoloogiast}

Looduslikud (mittekultiveeritud) süsteemid on nii suures osas kui võimalik häälestatud energia kasutamise ökonomiseerimisele ja toodavad seetõttu minimaalsel hulgal entroopiat. Artiklis pakutakse välja, et see on saavutatud evolutsiooniliselt, luues optimaalsed semiootilised kontrollmehhanismid kõigile eluprotsessidele. Senikaua kui bioloogilise (lõppkokkuvõttes fotosünteetilise) energia allikad rahuldasid enamiku inimese energiavajadusest, jäid need biosemiootilised kontrollmehhanismid valdavalt häirimata, mille tulemusena olid ka tootmissüsteemid jätkusuutlikud. Tööstusrevolutsioon lõpetas järsult selle tasakaalustatud olukorra. Semiootilise kontrolli funktsioon $(S)$ ei vastanud enam energiavoo suurusele $(E)$. Industriaalses tootmissüsteemis on energiavood tunduvalt kasvanud, samas kui $S$-komponendi eest pole hoolt kantud. See on tinginud ohtlikult madala $S / E$ suhte ja artiklis arvatakse, et see madal $S / E$ suhe moodustabki põhilise seletuse ökokriisile. Jätkusuutliku tootmissüsteemi taastamiseks tuleb nüüd arendada tehnilisi vahendeid suurendamaks märkimisväärselt tootmissüsteemi $S$-faktorit. Pakutakse, et see on saavutatav, arendades välja biosemiootilise tehnoloogia paindlikud, mahedad ja targad vormid. 